\title{
Examination of the Etiologic Causes in Patients Presenting with Elevated Parathormone
}

\author{
Parathormon Yüksekliği ile Başvuran Hastalarda Etiyolojik Nedenlerin Incelenmesi
}

(D) Idris Kırhan, (D) Mehmet Ali Eren*

Harran University Faculty of Medicine, Department of Internal Medicine, Şanlıurfa, Turkey

*Harran University Faculty of Medicine, Department of Endocrinology, Şanlıurfa, Turkey

\section{Abstract}

Objective: Parathyroid hormone (PTH) levels are elevated in the blood due to various reasons and named as primary or secondary hyperparathyroidism. There is no any study that investigated the etiology of elevated PTH.

Materials and Methods: The study included 137 patients who had elevated PTH, which was detected in blood tests that were performed due to any reason, during 1-year period.

Results: Of all patients 118 (86.1\%) were female and 19 (13.9\%) were male. Vitamin D deficiency was found in 88 (64.2\%), primary hyperparathyroidism (PHPT) in 38 (27.7\%), familial hypocalciuric hypercalcemia (FHH) in 8 (5.8\%), and chronic renal failure (CRF) in 3 (2.2\%) patients.

Conclusion: Vitamin D deficiency is a common disorder in general population, and occasionally coexisted with increased PTH level. Therefore, vitamin D deficiency should be kept in mind when PTH studied as a first test and is found to be high. The other reason such as PHPT, FHH and CRF must be also investigated.

Keywords: Parathormone, etiologic causes, vitamin D deficiency

\section{Öz}

Amaç: Parathormon (PTH) düzeyi kanda çeşitli nedenlerle yükselir ve primer veya sekonder hiperparatiroidizm olarak adlandırılır. PTH yüksekliğinin etiyolojisini araştıran herhangi bir çalışma yoktur.

Gereç ve Yöntem: Çalışmaya 1 yıllık süre içerisinde herhangi bir sebeple yapılan kan testlerinde saptanan PTH yüksek bulunmuş 137 hasta dahil edildi.

Bulgular: Tüm hastaların 118'i (\%86,1) kadın, 19'u (\%13,9) erkekti. D vitamini eksikliği 88'inde (\%64,2), primer hiperparatiroidizm (PHPT) 38 'inde \%27,7'sinde ailesel hipokalsiürik hiperkalsemi $(\mathrm{AHH}), 8^{\prime}$ inde $(\% 5,8)$ ve 3'ünde $(\% 2,2)$ kronik böbrek yetmezliği (KBY) tespit edildi. Sonuç: D vitamini eksikliği, genel popülasyonda sık görülen bir hastalıktır ve bazen artan PTH düzeyi ile birlikte bulunur. Bu nedenle, PTH ilk test olarak okunduğu ve yüksek olduğu tespit edildiğinde D vitamini eksikliği akılda tutulmalıdır. PHPT, AHH ve KBY gibi diğer sebepler de araştırılmalıdır.

Anahtar kelimeler: Parathormon, etiyolojik nedenler, D vitamin eksikliği

\section{Introduction}

Parathyroid hormone (PTH) is a peptide hormone secreted from parathyroid glands into the circulation and its main effect is to provide serum calcium homeostasis (1). PTH levels are elevated in the blood due to various reasons. The most important cause is primary hyperparathyroidism (PHPT). This is characterized by an increase in serum calcium levels as a result of autonomically over secretion of PTH from parathyroid glands (2). Whereas secondary hyperparathyroidism (SHPT) occurs due to the stimulation of parathyroid glands as a result of dysfunction in one or more mechanisms in providing calcium homeostasis of the body, which result in increased PTH secretions (3). SHPT often develops as a result of chronic renal failure (CRF) or vitamin D deficiency (3).

In clinical practice, PTH levels are studied in order to investigate the etiology when a decrease or increase is detected in

Address for Correspondence/Yazışma Adresi: İdris Kırhan MD, Harran University Faculty of Medicine, Department of Internal Medicine, Şanlıurfa, Turkey Phone: +90 5322095463 E-mail: idriskirhan@gmail.com ORCID ID: orcid.org/0000-0001-6606-6078 Received/Geliş Tarihi: 31.07.2019 Accepted/Kabul Tarihi: 08.11.2019 
calcium values. However, PTH levels are ordered with initial investigations especially in persons with osteoporosis detected, and a confusion occurs when elevated PTH levels are found In this case, CRF, vitamin D deficiency, absorption disorders, the use of lithium, and familial hypocalciuric hypercalcemia $(\mathrm{FHH})$ that can cause SHPT should be first ruled out. After ruling out these causes, the diagnosis of normocalcemic PHPT is established (4). Although the most important causes of PHPT and SHPT are known, there is no any study about the cause of this condition when elevated PTH is initially found.

In this study, we aimed to reveal the causes of elevated PTH by screening information of patients with elevated PTH who were referred to our outpatient clinic.

\section{Materials and Methods}

In this study, 137 patients who had elevated PTH, which was detected in blood tests that were performed due to any reason, and were referred to the endocrinology outpatient clinic of Harran University Faculty of Medicine during 1-year period from January 2018 through March 2019 were retrospectively studied. Patients' age, gender, serum levels of calcium, phosphorus, magnesium, albumin, creatinine, 25 hydroxy vitamin D and PTH values, and spot urine calcium and creatinine levels were recorded from the hospital records. If 24-h urine was collected and daily calcium excretion was calculated, these values were also recorded. Patients receiving renal replacement therapy were excluded from the study. Also data of the patients who underwent parathyroid ultrasonography and scintigraphy upon suspected PHPT were recorded. The necessary permission was obtained from the hospital board in order to use the data. The study protocol was approved by the local ethics committee. Serum PTH samples were studied with immulite 2000 using chemiluminescence assay. Informed consents from patient were taken

\section{Statistical Analysis}

Continuous variables are expressed as mean (minimummaximum), and categorical variables as $n(\%)$. The data between groups were compared with Kruskal-Wallis and Mann-
Whitney $U$ tests. The statistical analysis was performed using SPSS version 20.0 software.

\section{Results}

A total of 137 patients were included in the study. Of all patients $118(86.1 \%)$ were female and $19(13.9 \%)$ were male. The mean age was found as $54.6 \pm 16.2$ (19-99) in overall patients, $54.1 \pm 16.2$ (19-96) in the female and $57.6 \pm 15.9$ (28-85) in the male patients. According to the investigations performed; vitamin D deficiency was found in $88(64.2 \%)$, PHPT in 38 (27.7\%), $\mathrm{FHH}$ in $8(5.8 \%)$, and CRF in $3(2.2 \%)$ patients. The mean creatinine values of the patients was found as $0.73 \pm 0.16$ (0.4-1.5), the mean calcium value as $9.90 \pm 0.87$ (8-12), the mean phosphorus value as $3.09 \pm 0.60$ (1.9-5.1), the mean PTH value as $176.2 \pm 72.5$ (90-476), and the mean vitamin D level as $15 \pm 11.8$ (2.4-65). The mean 24-h urine calcium level was found as $(n=44) 259 \pm 178.9(22-910)$ and the mean calcium clearance $(n=86)$ as $0.011 \pm 0.009(0.007-0.431)$.

Afterwards, the data were compared according to the etiological causes (vitamin D deficiency, PHPT and FHH). CRF was not take into account since the small number of participant $(n=3)$. Calcium levels were highest in PHPT group, and lowest in vitamin $\mathrm{D}$ deficiency; there were significantly differences between all groups. Phosphorus levels were significantly lower in PHPT group when compared to the other two groups. Furthermore, calcium clearance levels were higher in PHPT group according to the other two groups. All of the parameters and $p$ values were shown in Table 1.

\section{Discussion}

PTH primarily leads to transmission of calcium to the bloodstream by increasing bone resorption. In addition, it increases the synthesis of 1.25-dihydroxy vitamin D3 in the kidneys. Thus, intestinal calcium absorption increases (5). When PTH is over secreted due to reasons such as adenoma hyperplasia or parathyroid cancer, it may be found elevated in the blood together with increased calcium level. In addition, there may be also a secondary elevation in order to compensate for unexpected changes in blood calcium levels such as in case of

Table 1. Comparison of parameters according to etiological cause

\begin{tabular}{|c|c|c|c|c|}
\hline & $\begin{array}{l}\text { Vitamin D deficiency } \\
(n=88)\end{array}$ & $\begin{array}{l}\text { PHPT } \\
(n=38)\end{array}$ & $\begin{array}{l}\text { FHH } \\
(n=8)\end{array}$ & $p$ \\
\hline $\mathrm{Ca}^{*}$ & $9.8 \pm 0.6^{a^{*}, b^{\star *}}$ & $10.9 \pm 0.6^{c^{\star \star \star}}$ & $10.2 \pm 1.0$ & $\begin{array}{l}{ }^{*}<0.001 \\
{ }^{* *} 0.035 \\
{ }^{* * *} 0.027\end{array}$ \\
\hline$P^{*}$ & $3.26 \pm 0.58^{\mathrm{a}^{*}}$ & $2.76 \pm 0.49^{\star \star *}$ & $3.2 \pm 0.64$ & ${ }^{*}<0.001$ \\
\hline $\mathrm{Mg}$ & $1.97 \pm 0.21$ & $1,96 \pm 0,25$ & $1,84 \pm 0,23$ & NS \\
\hline PTH & $166 \pm 72.8$ & $201 \pm 95$ & $142.5 \pm 24.7$ & NS \\
\hline Ca clearance* & $0.0078 \pm 0.005^{a^{*}}$ & $0.0185 \pm 0.009^{c^{*}}$ & $0.047 \pm 0.0015$ & ${ }^{*}<0.001$ \\
\hline
\end{tabular}

a: between "vitamin D deficiency" and "PHPT", b: between "vitamin D deficiency" and "FHH", c: between "PHPT" and "FHH". PHPT: Primary hyperparathyroidism, FHH: Familial hypocalciuric hypercalcemia, PTH: Parathyroid hormone 
CRF or vitamin D deficiency (6). When PTH is studied due to any reason and found to be elevated, there may be multiple causes of this elevation.

First, calcium value should be measured in order to make differential diagnosis of elevated PTH. Differential diagnosis of PHPT and FHH should be established in patients with high blood calcium levels detected. While urine calcium excretion is increased in PHPT, it is decreased in FHH because of the mutation in calcium sensitizer receptors (CaSR) (7). Similarly the use of lithium may antagonize CaSR, causing hyperparathyroidism, hypercalcemia, and hypercalciuria (8). Therefore the use of lithium should be questioned before making a differential diagnosis.

In $\mathrm{CRF}$, when glomerular filtration rate drops under $60 \mathrm{~mL} /$ $\mathrm{min} / 1.73 \mathrm{~m}^{2}, \mathrm{PTH}$ begins to elevate mainly as a physiological response in order to compensate elevated phosphorus (9). Phosphorus level increases with progression of renal failure, and this increase leads to a decrease in calcium levels. In addition, vitamin $D$ related intestinal calcium absorption is also disrupted because 1-alpha-hydroxylase activity will also decrease in this case. As a result, PTH level elevates and SHPT occurs (10).

Another cause of SHPT is vitamin D deficiency. Vitamin D deficiency is common in the general population (11). While about one billion people experience vitamin D deficiency, $50 \%$ of the general population have vitamin D insufficiency worldwide (12). In a recent study from Ankara province of our country, Oksuz et al. (13) found vitamin D deficiency by very high rates of (51.8\%), and vitamin D insufficiency by $20.7 \%$. There is an inverse association between $25-\mathrm{OH}$ vitamin $\mathrm{D}$ and PTH levels. When vitamin D level decreases, parathyroid glands augment the synthesis and secretion of PTH. Elevated PTH accompanies $20-45 \%$ of patients with vitamin D deficiency (14). Normocalcemic hyperparathyroidism (ncHPT) is constantly normal serum calcium levels and elevated PTH levels without any secondary cause that will lead to elevation in PTH levels $(15,16)$. In order to establish the diagnosis of ncHPT both total and ionized calcium levels should be within normal limits. It is recommended that $25-\mathrm{OH}$ vitamin D levels should be elevated above $30 \mathrm{ng} / \mathrm{mL}(75 \mathrm{nmol} / \mathrm{L})$ in order to make the diagnosis of ncHPT (15). Sometimes normocalcemic patients may become hypercalcemic when 25-OH vitamin D levels exceed $30 \mathrm{ng} / \mathrm{mL}$. PHPT is the most common cause of hypercalcemia together with malignancies. Although its incidence is decreasing it is still 15/100000. The incidence in the United States of America is estimated as 66/100000 persons per year in women and $25 / 100000$ persons per year in men (12). PHPT is a common endocrine disease biochemically characterized by hypercalcemia and increased or improper normal PTH levels. PHPT is more common in elderly population and its prevalence is up to $2 \%$ (17). It is caused by a single parathyroid adenoma in many cases $(80 \%)$, more rarely by multiple gland disorder (e.g. multiple adenomas or multiple gland parathyroid hyperplasia), and rarely $(<1 \%)$ by parathyroid carcinoma (18). $\mathrm{FHH}$ is an autosomal dominant-pattern hereditary conditions which is equally distributed in both sexes. The prevalence of $\mathrm{FHH}$ is estimated as 1/78000, but it is possibly underestimated because of its subclinic nature (19). In PHPT, hypercalcemia is accompanied by low phosphorus value, while calcium and phosphorus levels remain low in vitamin D deficiency $(14,20)$. The laboratory findings of FHH can imitate the PHPT with high calcium and normal/low phosphorus levels (19). In accordance with this information, the highest calcium and the lowest phosphorus levels were observed in the PHPT group in our study. On the other hand, a calcium clearance level was higher in PHPT group when compared to the other two groups. It is well known that PHPT accompanied with overflow hypercalciuria, while low calcium clearence levels are seen in the case of vitamin $\mathrm{D}$ deficiency and $\mathrm{FHH}$ (7). Best to the knowledge, there was no study in the literature that investigates the etiology of PTH elevation. In our retrospective study, the most common reason of elevated PTH was vitamin D deficiency (64.2\%), and the others were respectively as PHPT (27.7\%), FHH (5.8\%), and CRF (2.2\%).

\section{Conclusion}

In conclusion, vitamin D deficiency is a common disorder in general population, and occasionally coexisted with increased PTH level. Therefore, vitamin D deficiency should be kept in mind when PTH studied as a first test and is found to be high. The other reason such as PHPT, FHH and CRF must be also investigated.

\section{Ethics}

Ethics Committee Approval: The study were approved by the Harran University of Local Ethics Committee (protocol number: 19.01.18).

Informed Consent: Informed consents from patient were taken.

Peer-review: Externally peer- reviewed.

\section{Authorship Contributions}

Surgical and Medical Practices: M.A.E., I.K., Concept: I.K., Design: M.A.E., I.K., Data Collection or Processing: M.A.E., I.K., Analysis or Interpretation: M.A.E., I.K., Literature Search: I.K., Writing: i.K.

Conflict of Interest: No conflict of interest was declared by the authors.

Financial Disclosure: The authors declared that this study received no financial support.

\section{References}

1. Murray TM, Rao LG, Divieti P, Bringhurst FR. Parathyroid hormone secretion and action: evidence for discrete receptors for the carboxyl-terminal region and related biological actions of carboxylterminal ligands. Endocrine Rev 2005;26:78-113.

2. Wermers RA, Khosla S, Atkinson EJ, Hodgson SF, O'Fallon WM, Melton LJ 3rd. The rise and fall of primary hyperparathyroidism: a population-based study in Rochester, Minnesota, 1965-1992. Ann Intern Med 1997:126:433-40.

3. Costa-Guda J, Arnold A, Chapter 33 - Hyperparathyroidism, Genetics of Bone Biology and Skeletal Disease (Second Edition), 
Academic Press, Editor(s): Rajesh V. Thakker, Michael P. Whyte John A. Eisman, Takashi Igarashi, 599-615, 2018.

4. Chen $G$, Xue $Y$, Zhang Q, Xue T, Yao J, Huang $H$, et al. Is Normocalcemic Primary Hyperparathyroidism Harmful or Harmless? J Clin Endocrinol Metab 2015;100:2420-4

5. Kumar R, Thompson JR. The regulation of parathyroid hormone secretion and synthesis. J Am Soc Nephrol 2011;22:216-24.

6. Cozzolino M, Galassi A, Conte F, Mangano M, DiLullo L, Bellasi A Treatment of secondary hyperparathyroidism: the clinical utility of etelcalcetide. Ther Clin Risk Manag 2017;13:679-89.

7. Shinall MC Jr, Dahir KM, Broome JT. Differentiating familial hypocalciuric hypercalcemia from primary hyperparathyroidism. EndocrPract 2013;19:697-702.

8. Meehan $A D$, Udumyan $R$, Kardell $M$, Landén $M$, Järhult J, Wallin G. Lithium-Associated Hypercalcemia: Pathophysiology, Prevalence, Management. World J Surg 2018;42:415-24.

9. Yuen NK, Ananthakrishnan S, Campbell MJ. Hyperparathyroidism of Renal Disease. Perm J 2016;20:15-127.

10. Messa P, Alfieri CM. Secondary and Tertiary Hyperparathyroidism. Front Horm Res 2019;51:91-108.

11. Sowah $D$, Fan $X$, Dennett $L$, Hagtvedt $R$, Straube S.Vitamin $D$ levels and deficiency with different occupations: a systematic review. BMC Public Health 2017;17:519.

12. Yeh MW, Ituarte PH, Zhou HC, Nishimoto S, Liu IL, Harari A, et al. Incidence and prevalence of primary hyperparathyroidism in a racially mixed population J Clin Endocrinol Metab. 2013;98:1122-

13. Oksuz A, Kutlu R. Meram Tıp Fakültesi Hastanesi Aile Hekimliği Polikliniğine Başvuran Hastaların D Vitamini Düzeylerinin Değerlendirilmesi Konuralp Tıp Dergisi 2018;10:160-4.

14. Alarcón T, González-Montalvo Jl, Hoyos R, Diez-Sebastián J, Otero A, Mauleon JL. Parathyroid hormone response to two levels of vitamin D deficiency is associated with high risk of medical problems during hospitalization in patients with hip fracture J Endocrinol Invest 2015;38:1129-35.

15. Cusana NE, Silverberg SJ, Bilezikian JP. Normocalcemic primary hyperparathyroidism. J Clin Densitom 2013;16:33-9

16. Diaz-Soto G, Julian MT, Puig-Domingo M. Normocalcemic primary hyperparathyroidism: a newly emerging disease needing therapeutic intervention. Hormones (Athens) 2012:11:390-6

17. Calo PG, Medas F, Loi G, Pisano G, Sorrenti S, Erdas E, et al. Parathyroidectomy for primary hyperparathyroidism in the elderly: experience of a single endocrine surgery center. Aging Clin Exp Res 2017;29:15-21.

18. Bilezikian JP, Bandeira L, Khan A, Cusano NE Hyperparathyroidism. Lancet 2018;391:168-78.

19. Michigami T. Disorders Caused by Mutations in Calcium-Sensing Receptor and Related Diseases. ClinCalcium 2017;27:521-27.

20. Machado NN, Wilhelm SM. Diagnosis and Evaluation of Primary Hyperparathyroidism. Surg Clin North Am 2019;99:649-66. 